\title{
Pinus massoniana bark extract selectively induces apoptosis in human hepatoma cells, possibly through caspase-dependent pathways
}

\author{
HONGLING MA ${ }^{1}$, BING LIU ${ }^{1}$, DONGRU FENG ${ }^{1}$, HENG XIE $^{2}$, RUODA LI ${ }^{2}$, \\ YIXING YUCHI $^{1}$, HONGBIN WANG $^{1}$ and JINFA WANG ${ }^{1}$
}

\begin{abstract}
${ }^{1}$ The State Key Laboratory of Biocontrol and The Key Laboratory of Gene Engineering of the Ministry of Education, School of Life Sciences, Sun Yat-sen (Zhongshan) University, Guangzhou 510275; ${ }^{2}$ Institute of

Songzhen Nutritional Resource, Guangzhou 510645, Guangdong Province, P.R. China
\end{abstract}

Received November 27, 2009; Accepted January 5, 2010

DOI: 10.3892/ijmm_00000401

\begin{abstract}
Pinus massoniana bark extract (PMBE) is a mixture of flavonoids, whose antioxidant and apoptosisinducing properties have been confirmed in vitro. In this study, the apoptotic effect and mechanism of PMBE in HepG2 human hepatoma cells were evaluated. PMBE exerted dose- and time-dependent cell growth inhibition on HepG2 cells, and selectively induced apoptosis without impact on normal liver L-02 cells. Apoptosis induced by PMBE in HepG2 cells was also confirmed by annexin-V/PI staining, transmission electron microscopy and sub-G1 phase accumulation. Moreover, PMBE also slightly blocked the cell cycle in the G2/M and S phases in HepG2 cells. The investigation of the mechanism by which PMBE induced apoptosis in HepG2 cells indicated that activation of extrinsic and intrinsic caspase, inhibition of NF- $\mathrm{NB}$ activation and decrease of the antiapoptotic protein $\mathrm{Bcl}-2$ and the intact Bid protein were involved. Furthermore, the antitumor activity of PBME was demonstrated in vivo by a 42.88 $69.94 \%$ reduction rate of tumor weight in $\mathrm{H} 22$ tumor-implanted mice. Taken together, these data indicate that PMBE selectively induces apoptosis in HepG2 cells through caspase-dependent pathways, and inhibits tumor growth in vivo, making it a potential candidate for anticancer therapeutics.
\end{abstract}

\section{Introduction}

Hepatocellular carcinoma is one of the most common malignant cancers worldwide, according to statistics from the International Agency for Research on Cancer in 2002. Though operative resection is still the most effective treatment (1), only

Correspondence to: Dr Hongbin Wang, The State Key Laboratory of Biocontrol and The Key Laboratory of Gene Engineering of the Ministry of Education, School of Life Sciences, Sun Yat-sen (Zhongshan) University, Guangzhou 510275, P.R. China

E-mail: wanghb@mail.sysu.edu.cn

Key words: Pinus massoniana, caspase, Bcl-2
$20 \%$ of patients are suitable for surgery. Therefore, optimal comprehensive therapy, combining different nonsurgical therapies such as chemotherapy, biological therapy and traditional Chinese medicine, has become the main trend (2). Moreover, development of effective therapies capable of discriminating between tumor and normal tissue are receiving considerable attention in the field of anticancer studies (3).

Apoptosis is a cellular suicide program that eliminates unwanted, defective and potentially dangerous cells during the development and maintenance of cell homeostasis (4). Inducing apoptosis is a primary approach to eliminating cancer cells without stimulating an inflammatory reaction. Regulation of apoptotic signaling networks involves a complicated system consisting of numerous elements. Several conventional drugs are presently used in anticancer chemotherapy which are believed to induce cell apoptosis via activation of these elements (5).

In recent years, interest in natural plant components with potential cancer inhibiting effects has grown. Polyphenols are one type of these important compounds, and flavonoids are the most abundant polyphenols. They exert multiple biological effects including vascular protection, anti-inflammatory and -allergic responses, and antiviral and -tumor activities $(6,7)$. The pine tree contains many flavonoids (8). Pinus massoniana Lamb, of the Pinaceae family, is an indigenous tree found throughout China. Its needles, bark, pollen and turpentine have been used in Chinese folk medicine for treatment of hemorrhage, rheumatism, arthralgia, inflammation and cancer, and it is listed in Shennongbencaojing and the Pharmacopoeia of the P.R. China. HPLC analysis indicated that PMBE contains several polyphenolic compounds, such as taxifolin, epicatechin and epigallocatechin galloate (unpublished data). We have found that Pinus massoniana bark extract (PMBE) has strong, dose-dependent antioxidant and radical-scavenging activities, that compare favorably to well-known antioxidants such as $\alpha$-tocopherol, butylated hydroxyanisole, butylated hydrosytoluene and quercetin (9).

Our previous studies show that PMBE selectively suppresses proliferation of human liver cancer Bel-7402 cells without impacting the growth of normal liver L-02 cells (9). However, the effects and mechanisms of PMBE-induced 
apoptosis in other human hepatoma cells are not clearly defined. Human hepatoma HepG2 cells have similar biological activities as normal liver cells (10). Therefore, to explore whether PMBE distinguishes and displays different biological effects between normal liver cells and hepatoma cells, we investigated the effects of PMBE on proliferation and apoptosis in human hepatoma HepG2 cells, and elucidated the possible molecular mechanism. Our studies showed that treatment of HepG2 cells with PMBE significantly reduced the viability, correlating with a remarkably higher percentage of apoptosis inducement and a slight cell cycle arrest in the G2/M and $\mathrm{S}$ phases. Treatment of L-02 cells with PMBE had almost no inhibitory effect on viability. Our results also suggested that PMBE-induced apoptosis in HepG2 cells involved caspase activation, inhibition of nuclear factor- $\kappa \mathrm{B}(\mathrm{NF}-\kappa \mathrm{B})$ transcriptional activity and downregulation of antiapoptotic proteins Bcl-2 and Bid. Antitumor activity of PMBE was further demonstrated in vivo by a 42.88-69.94\% reduction rate of tumor weight in mouse hepatocellular carcinoma H22 tumor-implanted mice. These findings suggest a potential clinical application of PMBE for anticancer purposes.

\section{Materials and methods}

Materials. RPMI-1640 media, penicillin-streptomycin and trypsin were all obtained from Hyclone (Logan, UT, USA). Fetal bovine serume (FBS) was from Sijiqing (Hangzhou, China). Cell Counting Kit-8 (CCK-8) was from Dojindo Laboratories (Kumamoto, Japan). Cisplatin [cis-diaminedichloroplatinum (II), CP], cyclophosphamide (CTX), Hoechst33258, dimethylsulfoxide (DMSO), epigallocatechin galloate (EGCG) and vanillin reagents were from Sigma Chemical Co. (St. Louis, MO, USA). CP was prepared fresh as $50 \mathrm{mg} / \mathrm{ml}$ stocks in DMSO. Hoechst33258 was from Molecular Probes, Inc. Annexin-V/propidium iodide (PI) double staining assay kits were from Keygen Biotech Co. (Nanjing, China). Rabbit anti-human Bax, Bid, IкB- $\alpha$ and p-IкB- $\alpha$ polyclonal antibodies were from Cell Signaling Technology (Beverly, MA, USA). Mouse anti-human Bcl-2, caspase-9, -8, -3 and actin monoclonal antibodies were from Neomarker (Fremont, CA, USA). z-IETD-fmk, z-LEHD-fmk and z-VAD-fmk were from Calbiochem (San Diego, CA)

Preparation of extract from P. massoniana bark. P. massoniana bark was collected from Chenzhou, Hunan Province, China in May, 2005. The plant material was authenticated by an engineer from the Institute of Songzhen Nutritional Recourses (Guangdong, China). A voucher specimen (050500) was deposited in our laboratory for future reference.

PMBE was provided by the Institute of Songzhen Nutritional Recourses (Guangdong, China), and was prepared as previously described (11). In brief, after being screened, baked and crushed, pine bark powder $(1,000 \mathrm{~g})$ was extracted with boiling pure water $(2 \times 10,000 \mathrm{ml}, 20 \mathrm{~min}$ each $)$ and filtered through a fiber membrane to remove macroimpurities. Liquid was concentrated by filtering to remove saccharides, inorganic salts and water, and the final compound was spray dried. The extraction yield was $\sim 4 \%$ (wt/wt). PMBE was standardized by HPLC quantitation (HP 1100, Palo Alto, CA, USA), using EGCG as a reference standard.
PMBE powder was dissolved in DMSO to make a $100 \mathrm{mg} / \mathrm{ml}$ solution, which was sterilized through a $0.2 \mu \mathrm{m}$ Polytetrafluoroethylene microfilter (Milipore, Bedford, MA, USA) and stored at $-20^{\circ} \mathrm{C}$ for in vitro experiments. For cell treatment, the PMBE solution was diluted to $10 \mathrm{mg} / \mathrm{ml}$ with RPMI1640 media containing 10\% FBS, $100 \mathrm{U} / \mathrm{ml}$ penicillin and $100 \mu \mathrm{g} / \mathrm{ml}$ streptomycin. PMBE powder was dissolved in saline to make a $50 \mathrm{mg} / \mathrm{ml}$ solution, which was sterilized through a $0.2 \mu \mathrm{m}$ Millipore Express microfilter (Millipore, Carrighwohill, Ireland) and stored at $-20^{\circ} \mathrm{C}$ for in vivo experiment.

Estimates of proanthocyanidin. The content of proanthocyanidin in extracts was determined according to the $\mathrm{BuOH}-$ $\mathrm{HCl}$ method (12). The content of proanthocyanidin was determined based on a standard curve using proanthocyanidin (95\%, Jianfeng, Tianjin, China) as the standard, and expressed as $\mathrm{mg}$ of equivalents (E) per $\mathrm{g}$ of extract.

In brief, for the $\mathrm{BuOH}-\mathrm{HCl}$ assay, reaction mixtures consisted of $1 \mathrm{ml}$ of sample $(0.1 \mathrm{mg} / \mathrm{ml} \mathrm{PMBE}$ solution in methanol) or proanthocyanidin standard $(0.025-0.4 \mathrm{mg} / \mathrm{ml}$ proanthocyanidin solution in methanol), $6.0 \mathrm{ml}$ of $5 \%$ concentrated $\mathrm{HCl}$ in $1-\mathrm{BuOH}$, and $0.2 \mathrm{ml}$ of $2 \% \mathrm{NH}_{4}\left(\mathrm{SO}_{4}\right)_{2}$ $\cdot 12 \mathrm{H}_{2} \mathrm{O}$ in $2 \mathrm{~N} \mathrm{HCl}$. After mixing, reactions were heated at $95^{\circ} \mathrm{C}$ for $50 \mathrm{~min}$ in covered test tubes and then cooled with ice water. Absorbance at $550 \mathrm{~nm}$ was recorded. Absorbances of unheated reaction mixtures from representative plant samples and blank controls were compared to verify that plant pigments did not interfere with the assay.

Cell culture. Human hepatoma HepG2 and normal human hepatocellular L-02 were obtained from the Medical School of SUN Yat-sen University. Cells were grown in monolayer in RPMI-1640 media supplemented with 10\% FBS and 1\% penicillin-streptomycin in a $5 \% \mathrm{CO}_{2}$ humidified atmosphere at $37^{\circ} \mathrm{C}$.

CCK-8 assay for growth inhibition by PMBE. L-02 and HepG2 cells were cultured in a 96-well microplate at a density of $5 \times 10^{3}$ cells/well for $24 \mathrm{~h}$. Cells were treated with $2.4 \mu \mathrm{g} / \mathrm{ml}$ DMSO or $40-240 \mu \mathrm{g} / \mathrm{ml}$ of PMBE for $48 \mathrm{~h}$. Cells were treated with $10 \mu \mathrm{g} / \mathrm{ml}$ of $\mathrm{CP}$ for $48 \mathrm{~h}$ as a positive control, which was used as an importmant chemotherapeutic agent for cancer treatment. Cell cytotoxicity was assessed with CCK-8. The absorbance value at $450 \mathrm{~nm}$ was read with a Multiskan MK3 microplate reader (Thermo Labsystems, Helsinki, Finland), and was proportional to the growth activities of cells. The $50 \%$ inhibitory concentration (IC50) value was calculated by regression analysis. To determine the time-dependent effects of PMBE, HepG 2 cells were treated with $120 \mu \mathrm{g} / \mathrm{ml}$ of PMBE or $10 \mu \mathrm{g} / \mathrm{ml}$ of CP and CCK-8 assays were conducted at 12 , 24, 36, 48 and $72 \mathrm{~h}$. In experiments with caspase inhibitors, HepG2 cells were pre-treated with $50 \mu \mathrm{M}$ z-VAD-fmk, a general caspase inhibitor, z-IETD-fmk, the caspase- 8 inhibitor, or z-LEHD-fmk, the caspase-9 inhibitor, for a 2-h incubation before a 48-h incubation with $120 \mu \mathrm{g} / \mathrm{ml}$ PMBE. Cell viabilities were detected with CCK-8 assays.

Assay for change in cell morphology. After seeding on coverslips, L-02 and HepG2 cells were treated with $120 \mu \mathrm{g} / \mathrm{ml}$ of 
PMBE for 48 h. Cells were rinsed with phosphate-buffered saline (PBS) and incubated in $1 \mathrm{ml}$ of $10 \mu \mathrm{g} / \mathrm{ml}$ of Hoechst33258 and sheltered from light for $15 \mathrm{~min}$. Cells were rinsed with PBS, washed twice, and nuclear morphology was analyzed using a fluorescent microscope (Olympus BH-2, Osaka, Japan).

Annexin-V/PI staining. HepG2 cells $\left(5 \times 10^{5}\right)$ were seeded in $25 \mathrm{~cm}^{2}$ flasks. After $24 \mathrm{~h}$ of incubation, cells were treated with $0-160 \mu \mathrm{g} / \mathrm{ml}$ of PMBE for $24 \mathrm{~h}$ or $120 \mu \mathrm{g} / \mathrm{ml}$ of PMBE for 6 , $12,24,36$ and $48 \mathrm{~h}$. After treatment, floating cells were collected by centrifugation $(1,000 \times \mathrm{g}, 5 \mathrm{~min})$ and attached cells were trypsinized and collected. Cells were washed twice in PBS and then resuspended in a $1 \mathrm{x}$ binding buffer at a concentration of $10^{6}$ cells $/ \mathrm{ml}$ according to the manufacturer's protocol. Cells were then incubated with $10 \mu \mathrm{l}$ of fluorescein isothiocyanate-conjugated Annexin V (Annexin V-FITC) and $10 \mu 1$ of PI. Then they were analyzed on an Epics flow cytometer (FCM, Elite, Beckman Co., USA). Cells only stained with Annexin V-FITC were considered to be apoptotic cells that expressed phosphatidylserine in the outer layer of the cell membrane.

Transmission electron microscopy (TEM) analysis. HepG2 cells $\left(5 \times 10^{5}\right)$ were seeded in $25 \mathrm{~cm}^{2}$ flasks. After $24 \mathrm{~h}$, cells were treated with 0 or $120 \mu \mathrm{g} / \mathrm{ml}$ of PMBE for $48 \mathrm{~h}$. Floating cells were collected by centrifugation $(1,000 \mathrm{x} \mathrm{g}, 5 \mathrm{~min})$ and attached cells were trypsinized and collected. Cells were washed in PBS and fixed with $2.5 \%$ glutaraldehyde overnight, followed by osmium for $90 \mathrm{~min}$, both without resuspension. After washing with PBS three times for $10 \mathrm{~min}$, cells were dehydrated in an increasing gradient of ethanol (30, 50, 70, 80,90 and $95 \%$ ) rinsing cell pellets for $10 \mathrm{~min}$ at each change. Pellets were rinsed in acetone three times for $10 \mathrm{~min}$ to allow thorough dehydration. To prepare TEM samples, pellets were permeabilized in acetone-epoxy resin (1:1) mixture for $1 \mathrm{~h}$ followed by two rounds of permeabilization in epoxy resin for $1 \mathrm{~h}$ each, then immersed in epoxy resin overnight and baked at $70^{\circ} \mathrm{C}$ overnight. After cropping to suitable size, samples were analyzed under TEM (CM10 Philips, Mahwah, NJ).

Assessment of cell cycle by flow cytometry. To determine cell cycle distribution, $3 \times 10^{5} \mathrm{HepG} 2$ cells were plated in 6-well plates, incubated overnight and allowed to reach $70-80 \%$ confluency. Cells were treated with PMBE $(120 \mu \mathrm{g} / \mathrm{ml})$ for 24, 48 and $72 \mathrm{~h}$ or $\operatorname{PMBE}(0,80,120,160 \mu \mathrm{g} / \mathrm{ml})$ for $48 \mathrm{~h}$. After treatment, floating cells were collected by centrifugation $(1,000 \times \mathrm{g}, 5 \mathrm{~min})$ and attached cells were trypsinized and collected. Cells were washed in PBS and fixed in $70 \%$ ethanol at $4^{\circ} \mathrm{C}$ overnight. After fixing, cells were washed with PBS and resuspended in $200 \mu \mathrm{l}$ of PBS containing $20 \mu \mathrm{g} / \mathrm{ml}$ RNase A and $50 \mu \mathrm{g} / \mathrm{ml} \mathrm{PI}$, and incubated in the dark for $30 \mathrm{~min}$ at room temperature before analysis on an Epics flow cytometer (Elite, Beckman Co.). Cell cycle phase was determined using MultiCycle software (Phoenix Flow System, USA). The proportion of apoptotic cells was measured using WinMDI 2.9 software.

Protein extraction and immunoblotting analysis. Total protein was extracted with RIPA lysis buffer (PBS containing 1\%
NP40, $0.1 \%$ SDS, $0.5 \%$ sodium deoxycholate, $1 \mathrm{mM}$ sodium orthovanadate and $5 \mathrm{mM}$ EDTA) with $1 \%$ PMSF added before use. For each sample, $30 \mu \mathrm{g}$ of protein was separated by 12 or $15 \%$ SDS-polyacrylamide gel electrophoresis (PAGE) (Sigma). After electrophoresis, proteins were transferred to polyvinylidene fluoride membranes (Pall Corporation, East Hills, NY, USA). After washing in PBS, membranes were blocked in 5\% nonfat powder milk in PBS/T (PBS with $0.1 \%$ Tween-20). Individual membranes were incubated with primary antibodies against human caspase-8 $(1: 1,000)$, caspase-9 $(1: 1,000)$, caspase-3 $(1: 1,000)$, Bid $(1: 1,000)$, Bax $(1: 1,000), \mathrm{Bcl}-2$ (1:1,000), IкB- $\alpha(1: 1,000), \mathrm{p}-\mathrm{I} \kappa \mathrm{B}-\alpha(1: 1,000)$ and actin (1:800) in $\mathrm{PBS} / \mathrm{T}$ at $4^{\circ} \mathrm{C}$ overnight, with slight agitation. Membranes were washed in PBS/T three times and incubated in HRP-linked secondary antibodies $(1: 2,500)$ in $\mathrm{PBS} / \mathrm{T}$ at RT for $1 \mathrm{~h}$, with slight agitation. Detection was performed using the ECL Western blotting system (Amersham, Piscataway, NJ, USA) according to the manufacturer's instructions.

Determination of in vivo antitumor effect. Antitumor activity against a solid tumor mass was evaluated in Kunming mice. Kunming mice of either sex, weighing 18-20 g, specificpathogen free, were obtained from the Laboratory Animal Center of Guangdong and housed in a laminar air flow cabinet under pathogen-free conditions on a $12 \mathrm{~h}$ light $-12 \mathrm{~h}$ dark schedule. Ascites $\left(0.2 \mathrm{ml}\right.$ of $5 \times 10^{6}$ hepatoma cells H22) from tumor-bearing mice 7 days after tumor inoculation was subcutaneously implanted into the right armpit. Before treatment, forty mice were randomly selected and divided into five groups $(n=8)$ for drug injection. Treatments were initiated $24 \mathrm{~h}$ after the injection of tumor cells. One group (saline group) was given $0.9 \%$ saline intraperitoneally (i.p.), while other groups were injected i.p. with $20 \mathrm{mg} / \mathrm{kg}$ CTX or 100,200 or $300 \mathrm{mg} / \mathrm{kg}$ PMBE once a day for twelve consecutive days. Tested mice were sacrificed and tumor weights were recorded at day 13 . Their care was in accord with approved procedures of the Institutional Animal Care and Use Committee of the Chinese Academy of Medical Sciences. The antitumor activity of the treatments was evaluated in terms of inhibition rate (IR), which was calculated as IR $(\%)=(1-\mathrm{Wt} / \mathrm{Wc}) \cdot 100$, where $\mathrm{Wt}$ is the mean tumor weight of group injected i.p. with CTX or PMBE and Wc is the mean tumor weight of saline group.

Statistical analysis. All data are expressed as means \pm standard deviation (SD) from three independent experiments. Statistical significance was evaluated either by the two-tailed and unpaired Student's t-test or the one-way analysis of variance (ANOVA). A P-value $<0.05$ was considered statistically significant, and a P-value $<0.01$ was considered statistically very significant.

\section{Results}

Total proanthocyanidin content of PMBE. To determine the main components of $P$. massoniana extracts, the total proanthocyanidin content was measured. PMBE contained total proanthocyanidin at $734.967 \pm 31.243 \mathrm{mg} \mathrm{E} / \mathrm{g}$ of extract.

Concentration and time-dependent cell growth inhibition of $P M B E$ in L-O2 and HepG2 cells. To analyze the cell growth 
(A)

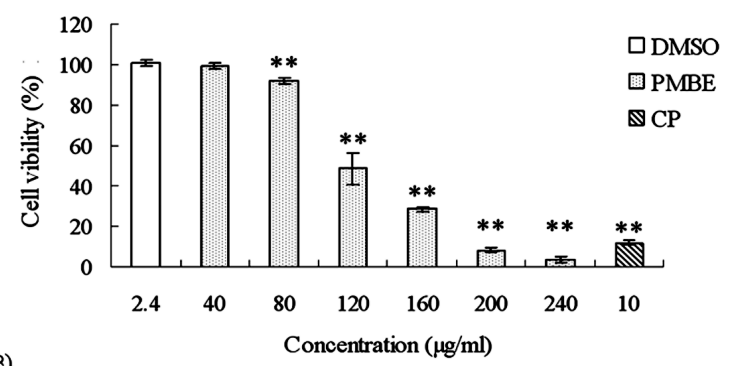

(B)

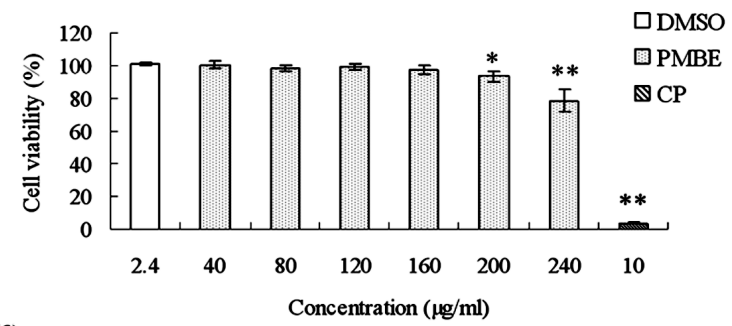

(C)

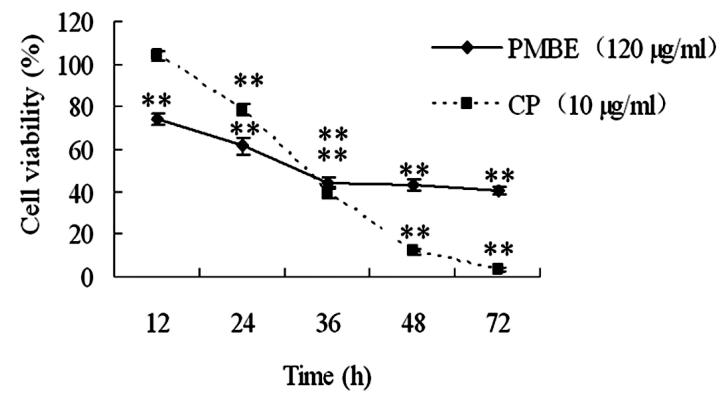

Figure 1. Effect of PMBE on growth of HepG2 and L-02 cells. (A) HepG2 cells were treated with $2.4 \mu \mathrm{g} / \mathrm{ml}$ of DMSO, or $40,80,120,160,200$ or $240 \mu \mathrm{g} / \mathrm{ml}$ of PMBE, or $10 \mu \mathrm{g} / \mathrm{ml}$ of $\mathrm{CP}$ for $48 \mathrm{~h}$ and cell viabilities were detected with CCK-8 assays. (B) L-02 cells were treated with $2.4 \mu \mathrm{g} / \mathrm{ml}$ of DMSO, or 40 , $80,120,160,200$ or $240 \mu \mathrm{g} / \mathrm{ml}$ of PMBE or $10 \mu \mathrm{g} / \mathrm{ml}$ of CP for $48 \mathrm{~h}$ and cell viabilities were detected with CCK-8 assays. (C) HepG2 cells were treated with $120 \mu \mathrm{g} / \mathrm{ml}$ of PMBE or $10 \mu \mathrm{g} / \mathrm{ml}$ of $\mathrm{CP}$, and CCK-8 assays were performed at $0,12,24,36,48$ or $72 \mathrm{~h}$ to detect cell viabilities. Values are expressed as means \pm SD from three independent experiments. ${ }^{*} \mathrm{p}<0.05$ and ${ }^{* *} \mathrm{p}<0.01$ represent significant differences between the experimental and control groups.

of PMBE-treated L-02 and HepG2 cells, CCK-8 assays were performed. After 48-h treatment with 0, 40, 80, 120, 160, 200 and $240 \mu \mathrm{g} / \mathrm{ml} \mathrm{PMBE}$ or $10 \mu \mathrm{g} / \mathrm{ml} \mathrm{CP}$ as the positive control, the CCK-8 assay results showed a dose-dependent decrease in viability of PMBE-treated HepG2 cells (Fig. 1A). PMBE exhibited little growth inhibition of L-02 cells, however, not until the concentration of PMBE was $>200 \mu \mathrm{g} / \mathrm{ml}$ (Fig. 1B). The IC50 value of PMBE on growth inhibition was 2359 and $125 \mu \mathrm{g} / \mathrm{ml}$ for L-02 and HepG2 cells, respectively. This suggested that PMBE selectively inhibited cell growth of cancerous cells, rather than normal cells. To determine the time course of action, HepG2 cells were treated with $120 \mu \mathrm{g} / \mathrm{ml}$ of PMBE or $10 \mu \mathrm{g} / \mathrm{ml} \mathrm{CP}$, and CCK-8 assays were conducted at 12, 24, 36, 48 and $72 \mathrm{~h}$. Cell viability of both PMBE and CPtreated HepG2 cells decreased gradually with time (Fig. 1C). Taken together, these results showed that PMBE inhibited cell viability in a dose- and time-dependent manner in HepG2 cells. Low dose PMBE $(40 \mu \mathrm{g} / \mathrm{ml})$ exhibited very little inhibition of HepG2 cell proliferation. Therefore higher doses, ranging from $80-160 \mu \mathrm{g} / \mathrm{ml}$, at which PMBE could significantly

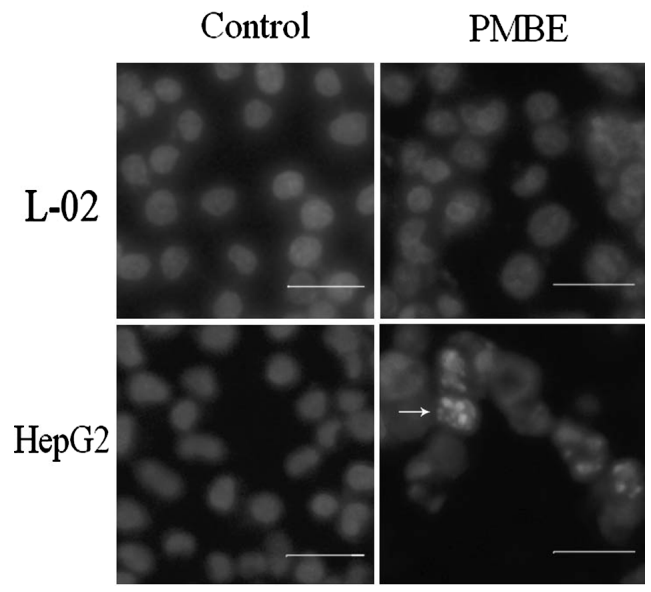

Figure 2. DNA fragmentation effect of PMBE in L-02 and HeLa cells. L-02 and HepG2 cells were treated with or without $120 \mu \mathrm{g} / \mathrm{ml}$ of PMBE for $48 \mathrm{~h}$ and nuclear morphological changes were detected by Hoechst staining. Arrows indicate apoptotic bodies of nuclear fragmentation. Scale bar, $25 \mu \mathrm{m}$.

inhibit HepG2 human hepatoma cell growth without impact on normal liver L-02 cells, were choosen for the subsequent experiments

DNA fragmentation induced in hepatoma cells by PMBE. To further investigate whether PMBE causes apoptosis in L-02 and HepG2 cells, Hoechst staining was performed. As shown in Fig. 2, condensed chromatin was observed in treated HepG2 cells, indicating apoptosis. These effects were not obvious in PMBE-treated L-02 cells, indicating that PMBE selectively induced apoptosis of cancer cells.

PMBE-triggered apoptosis in cancer cells. FCM analysis with annexin V/PI staining showed that when cells were exposed to different concentrations of $\operatorname{PMBE}(0,80,120$ and $160 \mu \mathrm{g} / \mathrm{ml})$ for $24 \mathrm{~h}$, the proportion of apoptotic cells increased from 3.5 to $79.2 \%$ (Fig. 3A). After 6, 12, 24 and $36 \mathrm{~h}$ of treatment with $120 \mu \mathrm{g} / \mathrm{ml}$ of PMBE in HepG2 cells, the proportion of apoptotic cells increased from 5.6\% in control cells to $78.9 \%$ in the PMBE-treated group (Fig. 3B). These results suggested that PMBE induced HepG2 cell apoptosis in a dose- and time-dependent manner.

To further investigate if the toxicity of PMBE was inducing apoptosis, HepG2 cells treated with $120 \mu \mathrm{g} / \mathrm{ml}$ of PMBE for $48 \mathrm{~h}$ were analyzed by transmission electron microscopy (Fig. 4). Control cells showed a lack of electron dense regions compared to the notable electron dense region in the nucleus of the extract-treated cells (Fig. 4A and B), which indicated that chromatin condensation was induced by PMBE. Plasma membrane blebbing and ultimate fragmentation of the cell into membrane-enclosed vesicles (apoptotic bodies) was also induced by PMBE (Fig. 4C and D).

Cell cycle assay. In order to investigate whether changes in cell cycle regulation were responsible for the observed antiproliferative effects of PMBE, the cell cycle distribution was evaluated using flow cytometric analysis. As shown in Table I, treatment of HepG2 cells with 80, 120 and $160 \mu \mathrm{g} / \mathrm{ml}$ PMBE appreciably increased the percentage of cells in the $\mathrm{G} 2 / \mathrm{M}$ phase from 11.4 to $25.0 \%$ after $24 \mathrm{~h}$ exposure compared with control. 
Table I. Effect of PMBE on cell cycle distribution in HepG2 cells.

\begin{tabular}{|c|c|c|c|c|c|}
\hline \multirow{2}{*}{$\begin{array}{l}\text { Time } \\
\text { (h) }\end{array}$} & \multirow{2}{*}{$\begin{array}{l}\text { Treatment } \\
(\mu \mathrm{g} / \mathrm{ml})\end{array}$} & \multirow{2}{*}{$\begin{array}{l}\text { Distribution } \\
\text { of sub-G1 }\end{array}$} & \multicolumn{3}{|c|}{ Distribution of cell cycle (\%) } \\
\hline & & & $\mathrm{G} 0 / \mathrm{G} 1$ & S & $\mathrm{G} 2 / \mathrm{M}$ \\
\hline \multirow[t]{4}{*}{24} & Control & $3.8 \pm 1.2$ & $66.5 \pm 4.9$ & $22.2 \pm 2.7$ & $11.4 \pm 2.6$ \\
\hline & PMBE (80) & $14.1 \pm 5.3^{*}$ & $61.0 \pm 1.7$ & $19.5 \pm 1.1$ & $19.5 \pm 1.0^{* *}$ \\
\hline & PMBE (120) & $30.7 \pm 5.4^{* *}$ & $58.2 \pm 3.8$ & $18.5 \pm 1.1$ & $23.3 \pm 3.3^{* *}$ \\
\hline & PMBE (160) & $50.5 \pm 11.8^{* *}$ & $49.9 \pm 4.1^{*}$ & $25.1 \pm 4.1$ & $25.0 \pm 3.3^{* *}$ \\
\hline \multirow[t]{4}{*}{48} & Control & $7.6 \pm 2.1$ & $70.4 \pm 5.2$ & $19.8 \pm 3.2$ & $9.3 \pm 2.0$ \\
\hline & PMBE (80) & $35.4 \pm 4.0^{* *}$ & $58.8 \pm 3.4^{*}$ & $26.0 \pm 1.8^{*}$ & $15.3 \pm 2.7^{*}$ \\
\hline & PMBE (120) & $54.1 \pm 4.9^{* *}$ & $53.0 \pm 2.3^{* *}$ & $26.8 \pm 2.4^{*}$ & $20.2 \pm 3.9^{* *}$ \\
\hline & PMBE (160) & $74.4 \pm 10.6^{* *}$ & $52.1 \pm 8.0^{*}$ & $31.4 \pm 6.4^{*}$ & $16.6 \pm 3.1^{*}$ \\
\hline \multirow[t]{4}{*}{72} & Control & $7.4 \pm 2.2$ & $72.3 \pm 4.6$ & $19.2 \pm 2.5$ & $8.4 \pm 2.4$ \\
\hline & PMBE (80) & $41.9 \pm 5.1^{* *}$ & $59.2 \pm 5.0^{*}$ & $28.7 \pm 3.0^{*}$ & $12.2 \pm 3.4$ \\
\hline & PMBE (120) & $70.3 \pm 5.8^{* *}$ & $56.8 \pm 4.9^{*}$ & $29.6 \pm 2.5^{* *}$ & $13.6 \pm 5.3$ \\
\hline & PMBE (160) & $79.5 \pm 3.7^{* *}$ & $56.0 \pm 1.6^{* * *}$ & $32.6 \pm 2.2^{* *}$ & $11.3 \pm 3.4$ \\
\hline
\end{tabular}

Numeric data are expressed as means \pm SD from three independent experiments, indicating proportion of cells in the sub-G1 and different cell cycle phases $(\mathrm{G} 0 / \mathrm{G} 1, \mathrm{~S}$, and $\mathrm{G} 2 / \mathrm{M})$. ${ }^{*} \mathrm{p}<0.05$ and ${ }^{* *} \mathrm{p}<0.01$ represent significant differences between the experimental and control groups.

(A)

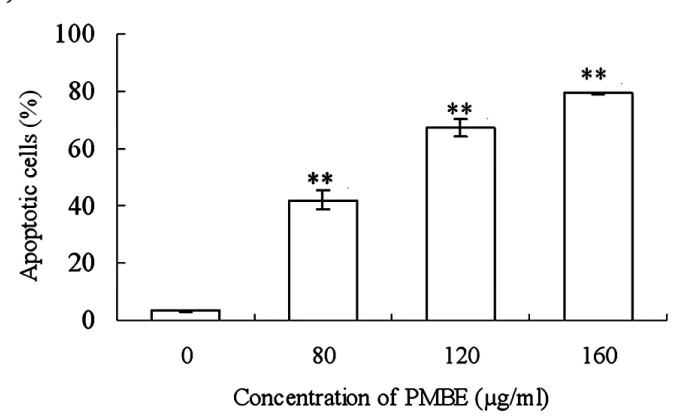

(B)

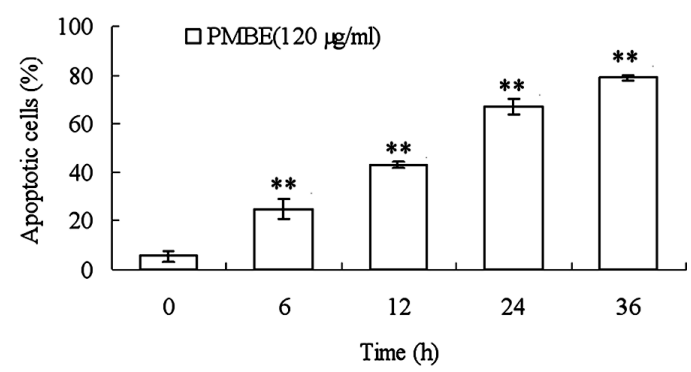

Figure 3. Effect of PMBE on apoptosis induction in HepG2 cells. (A) HepG2 cells were treated with $0,80,120$ or $160 \mu \mathrm{g} / \mathrm{ml}$ of PMBE for $24 \mathrm{~h}$. Apoptotic cells were determined by an annexin V-FITC/PI apoptosis detection kit. (B) HepG2 cells were treated with $120 \mu \mathrm{g} / \mathrm{ml}$ of PMBE and apoptotic cells were detected by an annexin V-FITC/PI apoptosis detection kit at $0,6,12,24,36$ or $48 \mathrm{~h}$. Cells stained with annexin V-FITC were considered to be apoptotic cells. Values are expressed as means \pm SD from three independent experiments. ${ }^{* *} \mathrm{p}<0.01$ represents significant differences between the experimental and control groups.

With increased time of PMBE treatment (48 and $72 \mathrm{~h}$ ), the proportion of cells arresting at $\mathrm{S}$ phase was increased, while the effect of $\mathrm{G} 2 / \mathrm{M}$ phase arrest was alleviated. Meanwhile, the proportion of cells at G0/G1 phase was reduced at 24-72 h after PMBE treatment. In addition, apoptotic cells, as judged from the appearance of a sub-G1 peak, were also observed at 24-

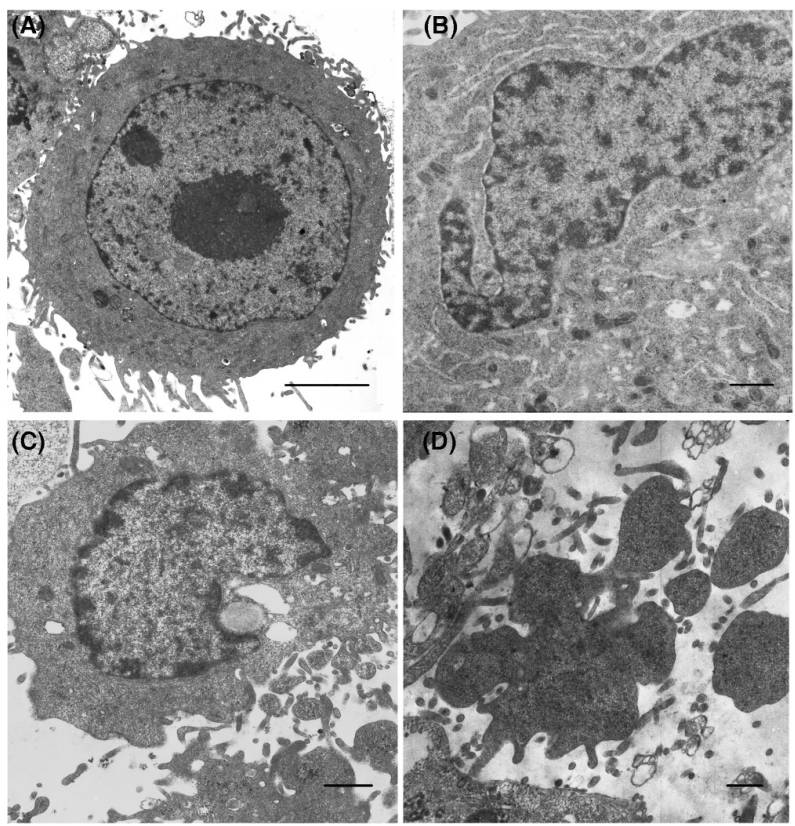

Figure 4. Morphology observation of HepG2 cells by TEM. HepG2 cells incubated without (A) or with (B-D) $120 \mu \mathrm{g} / \mathrm{ml}$ PMBE for $48 \mathrm{~h}$ examined by TEM. (A) Control HepG2 cell grown without PMBE. (B) Cells showing nuclear condensation. (C) Cells showing signs of membrane breakdown. (D) Apoptotic bodies in some cells, as well as evidence of cells entering apoptosis. Scale bar, $2.5 \mu \mathrm{m}$.

$72 \mathrm{~h}$ after PMBE treatment. Cells significantly accumulated in sub-G1 phase with increased time and PMBE concentration (Table I). These results indicated that PMBE induced cell cycle arrest in the $\mathrm{G} 2 / \mathrm{M}$ and $\mathrm{S}$ phases, as well as apoptosis in HepG2 cells.

Effect of PMBE on caspase activation. Since apoptosis induced by PMBE was observed in HepG2 cells, activation of the caspase family was investigated. To elucidate the apoptotic 
(A)
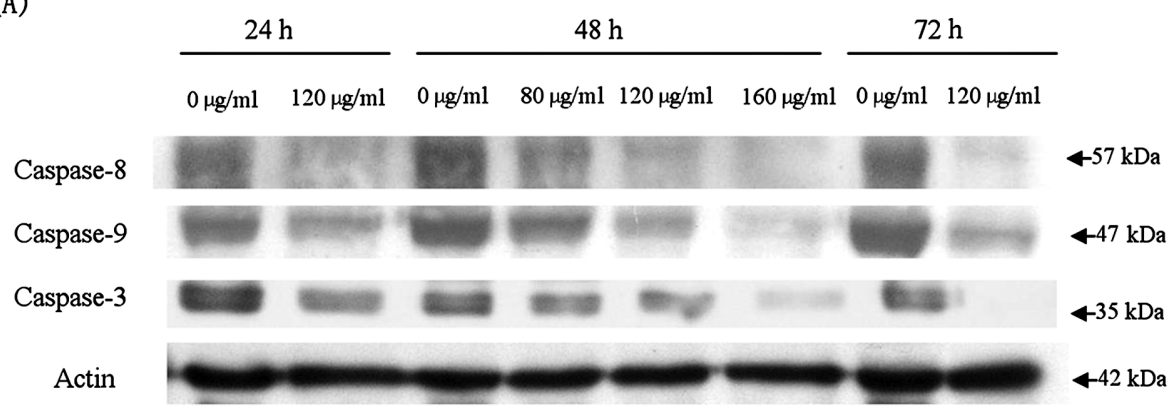

(B)

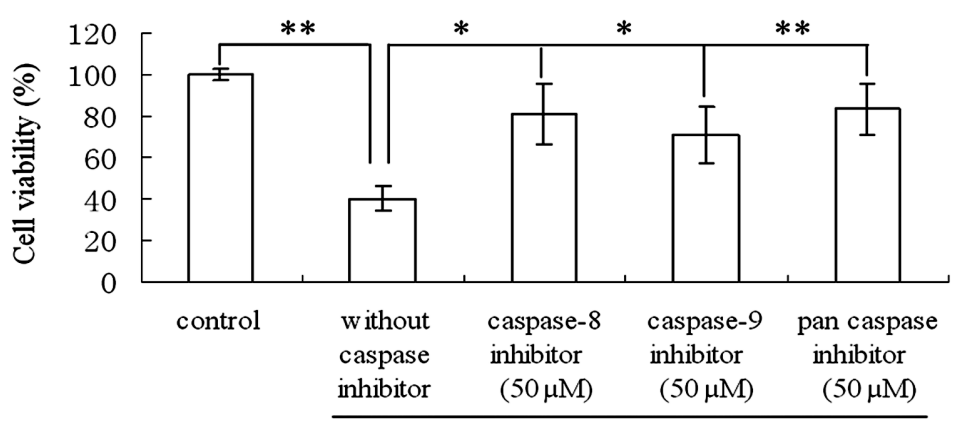

PMBE $(120 \mu \mathrm{g} / \mathrm{ml})$

(C)

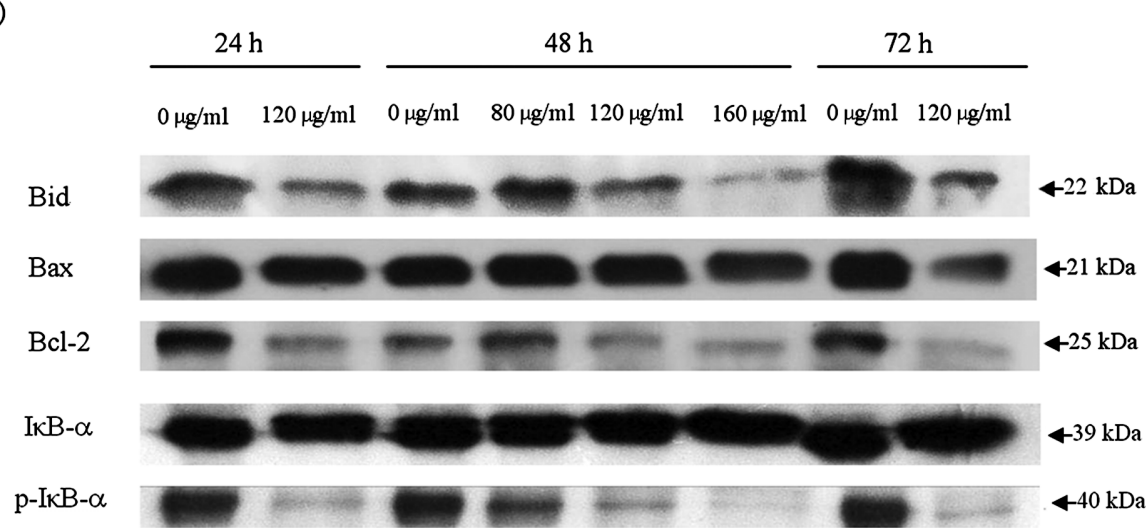

Figure 5. PMBE-induced apoptosis by activation of caspases and the effects of PMBE on regulation of apoptosis-related proteins. (A) Total extracts were analyzed to examine caspase activation. HepG2 cells were treated with PMBE at indicated concentrations, and equal amounts of total lysates were separated by SDS-PAGE and immunoblotted with anti-caspase-8, -9 and -3 . Actin was used as a loading control. (B) Caspase inhibitors prevented PMBE-induced reduction in cell viability. HepG2 cells pre-treated with $50 \mu \mathrm{M}$ z-IETD-fmk, z-LEHD-fmk and z-VAD-fmk for $2 \mathrm{~h}$ were incubated with $120 \mu \mathrm{g} / \mathrm{ml}$ PMBE for $48 \mathrm{~h}$, then cell viabilities were detected with CCK-8 assays. Results represent the mean of three different experiments. "p $<0.05$ and ${ }^{* *} \mathrm{p}<0.01$ represent significant differences between the experimental and control groups. (C) Total extracts were also used to examine the effect of PMBE on the basal expression level of Bid, Bax, Bcl-2, IкB- $\alpha$ and p-IкB- $\alpha$ proteins. HepG2 cells were treated with PMBE at indicated concentrations, and equal amounts of total lysates were separated by SDS-PAGE and immunoblotted with anti-Bid, anti-Bax, anti-Bcl-2, anti-IкB- $\alpha$ and anti-p-IкB- $\alpha$.

pathways involved in PMBE-treatment, we examined the expression of caspase- $3,-8$ and -9 by immunoblotting using antibodies that recognized the inactive forms of enzymes. HepG2 cells were treated with 80,120 or $160 \mu \mathrm{g} / \mathrm{ml} \mathrm{PMBE}$ for $48 \mathrm{~h}$, or $120 \mu \mathrm{g} / \mathrm{ml}$ PMBE for 24,48 , and $72 \mathrm{~h}$. Total extracts were blotted for the caspases. A reduction in the inactive forms of caspases-3, -8 and -9 was seen $24 \mathrm{~h}$ after treatment of HepG2 cells with PMBE, indicating that the caspases were activated by PMBE (Fig. 5A). To determine whether the activity of caspases was essential for apoptosis, the effect of z-VAD-fmk, a general caspase inhibitor, z-IETDfmk, a caspase- 8 inhibitor and z-LEHD-fmk, a caspase-9 inhibitor, was examined. As shown in Fig. 5B, pretreatment with $50 \mu \mathrm{M}$ z-IETD-fmk, z-LEHD-fmk or z-VAD-fmk for $2 \mathrm{~h}$ before the administration of PMBE prevented the decline in cell growth. These results indicated that PMBE-induced apoptotic cell death was caspase-dependent.

Effect of PMBE on apoptosis-related genes. The Bcl-2 family members can be subdivided into two groups according to their function, the antiapoptotic and the proapoptotic members (13). $\mathrm{Bcl}-2$ is an antiapoptotic protein that prevents the release of cytochrome c from mitochondria to the cytosol (14). We examined the expression of Bax and Bcl-2 levels in PMBEtreated HepG2 cells. Our results showed that Bax underwent no obvious changes after PMBE treatment. However, PMBE 
Table II. Tumor growth inhibitory effect of PMBE on H22 cells.

\begin{tabular}{lccc}
\hline Samples & $\begin{array}{c}\text { Dosage } \\
(\mathrm{mg} / \mathrm{kg})\end{array}$ & $\begin{array}{c}\text { Tumor weight } \\
(\mathrm{g})\end{array}$ & $\begin{array}{c}\text { Growth inhibition } \\
(\%)\end{array}$ \\
\hline Control & - & $2.87 \pm 0.67$ & - \\
CTX & 20 & $0.98 \pm 0.23^{* *}$ & 65.74 \\
PMBE & 100 & $1.64 \pm 0.31^{*}$ & 42.88 \\
PMBE & 200 & $1.24 \pm 0.24^{*}$ & 56.86 \\
PMBE & 300 & $0.87 \pm 0.17^{* *}$ & 69.94 \\
\hline
\end{tabular}

PMBE suppression of tumor growth in transplanted hepatoma H22 mice. Mice were injected with $\mathrm{H} 22$ cells as described in Materials and methods, and PMBE, at the dose of 100,200 or $300 \mathrm{mg} / \mathrm{kg}$, or CTX $20 \mathrm{mg} / \mathrm{kg}$ was applied by i.p. once a day for 12 days. Each group consists of 8 mice. Results are presented as mean \pm SD. ${ }^{*} \mathrm{p}<0.05$ and ${ }^{* *} \mathrm{p}<0.01$ represent significant differences between the experimental and control groups.

treatment greatly downregulated Bcl-2 expression (Fig. 5C), indicating that downregulation of $\mathrm{Bcl}-2$ protein is involved in the process of apoptosis induced in HepG2 cells by PMBE. Since PMBE may lead to caspase-9 activation, and Bid cleavage is often associated with caspase-9 activation (15), we examined the effects of PMBE on Bid (Fig. 5C). In HepG2 cells, the level of intact Bid decreased after PMBE treatment, suggesting that Bid underwent extensive cleavage upon PMBE treatment.

$\mathrm{NF}-\mathrm{kB}$ is the key transcription factor in the regulation of apoptosis by both mitochondrial (intrinsic) and death receptor (extrinsic) pathways (16). Since one of the target proteins regulated by NF- $\mathrm{KB}$ is $\mathrm{Bcl}-2$, whose expression decreased after PMBE treatment, we investigated if the activity of NF- $\mathrm{kB}$ is inhibited by PMBE. The results demonstrated that total expression of NF- $\mathrm{KB}$ inhibitor IкB- $\alpha$ was not altered, but the phosphorylation of IкB- $\alpha$ decreased in a dose- and timedependent manner after PMBE treatment of HepG2 cells (Fig. 5C), suggesting inhibition of NF-kB activity. Consistent with the decrease in expression of Bcl-2, the result suggested that inhibition of NF-kB activity is involved in the suppression of cell apoptosis.

Antitumor activity in H22 tumor-bearing mice. The results of assaying in vivo antitumor action of PMBE showed that after tumor implantation for $24 \mathrm{~h}$, administration of PMBE (100, 200 or $300 \mathrm{mg} / \mathrm{kg}$, i.p) and cyclophosphamide ( $20 \mathrm{mg} / \mathrm{kg}$, i.p) once a day for 12 days, significantly suppresses the growth of $\mathrm{H} 22$ tumors. The reduction rates of tumor weight were 42.88 , $56.86,69.94$ and $65.74 \%$, respectively (Table II). With higher PMBE dosages, the effect of PMBE was more marked. In addition, no marked body weight loss was observed in the PMBE treated group. This implies that PMBE is a candidate precursor substance for new anticancer therapeutics.

\section{Discussion}

Previously, we investigated the total flavonoid concentration of PMBE by $\mathrm{AL}\left(\mathrm{NO}_{3}\right)_{3}$ colorimentry and revealed that $1 \mathrm{~g}$
PMBE contained 271.429 $\pm 11.283 \mathrm{mg}$ quercetin equivalent of flavonoids (9). But total flavonoid concentration of PMBE is low and this method cannot reflect the proanthocyanidin content of PMBE. Many studies of pine bark extracts showed that the major constituents in pine bark extracts are proanthocyanidin $(17,18)$. Therefore, to explore whether proanthocyanidin is the main component in PMBE, the concentration of total proanthocyanidin was measured by the most commonly used colorimetric method, $\mathrm{BuOH}-\mathrm{HCl}$ assay, to quantify proanthocyanidin (19). Our results showed PMBE contained atotal proanthcyanidin at $734.967 \pm 31.243 \mathrm{mg} \mathrm{E} / \mathrm{g}$ of extract and indicated that proanthocyanidin is the main constituent of PMBE.

Pine bark extract has been reported to have apoptosisinducing activities against several kinds of cancer cells. For example, Huynh and Teel found that pycnogenol extracted from the bark of Pinus maritima selectively induces apoptosis in human mammary cancer cells (MCF-7) but not in normal human mammary MCF-10 cells (20). It also can induce differentiation and caspase-3-dependent apoptosis in leukemia cells HL-60, U937 and K562 (21). We have found that PMBE extracted from the bark of $P$. massoniana has the ability to induce apoptosis in Bel-7402 cells by downregulating the expression of the Bcl-2 protein (22). It also causes apoptosis in HeLa cells through the mitochondrial pathway (23). In this study, the IC50 value of PMBE on growth inhibition was $\sim 359$ and $125 \mu \mathrm{g} / \mathrm{ml}$ for L-02 and HepG2 cells, respectively, which suggested a selective cell viability inhibition by PMBE on human hepatoma HepG2 cells compared to normal L-02 human hepatic cells (Fig. 1). This is consistent with the expectation of different sensitivities to apoptotic inducement by PMBE (Fig. 2), from the study of Huynh and Teel (20). To further investigate the induction of apoptosis by PMBE in HepG2 cells, the FCM assay was employed after staining cells with annexin V/PI. PMBE was able to induce apoptosis in HepG2 cells as early as $6 \mathrm{~h}$ after treatment (Fig. 3). TEM also confirmed apoptotic inducement by PMBE in HepG2 cells (Fig. 4). Thus, differential sensitivity of apoptotic inducement to PMBE appeared to contribute to the selective growth inhibition of human hepatoma vs. normal cells. Results from the cell cycle assays (Table I) indicated cells were slightly arrested in G2/M phase at $24 \mathrm{~h}$ after PMBE treatment, but G2/M phase arrest decreased with longer PMBE treatment time, and $\mathrm{S}$ phase arrest increased in HepG2 cells. According to these findings, we hypothesized that the HepG2 cells arrested in G2/M phase were induced to undergo apoptosis before $24 \mathrm{~h}$ of PMBE treatment. But some cells whose cell cycle was not affected by PMBE continued to divide and go through the G1 phase. Then cells were subsequently arrested in S phase, and continuously induced into apoptosis by PMBE. Although the effects on G2/M and S phase arrest are notable, they are marginal compared to the pronounced effect observed on the sub-G1 phase when treated by the same dose of PMBE. These findings indicate that PMBE directly induces apoptosis, which is primary in cell cycle arrest for cell proliferation inhibition in HepG2 cells.

The extrinsic, caspase 8/Fas-Associated protein with Death Domain (FADD) death receptor pathway and intrinsic, mitochondrial pathway (24) are the two major signalling pathways regulating the apoptosis process. Caspases are crucial 
mediators of apoptosis. Caspase- 3 is an effector caspase, which can be activated by activation of an initiator caspase such as caspase- 8 or -9 , thus inducing subsequent apoptosis events (25). Immunoblotting (Fig. 5A) indicated that PMBE induced apoptosis in HepG2 cells through the activation of caspase-3, -8 , and -9 . To determine whether the activity of caspases was essential for apoptosis, cells were pretreated with caspase inhibitor before the administration of PMBE. These results (Fig. 5B) indicate that PMBE-induced apoptotic cell death was caspase-dependent. Interestingly, we found the inhibitory effects of the caspase- $8,-9$ and the pan-caspase inhibitors on PMBE-induced reduction of cell growth to be almost the same. This implied that the caspase-8/FADD death receptor pathway and the mitochondrial pathway are the main caspase apoptosis mediators that contribute to apoptosis induced by PMBE. Furthermore, it is likely that the two caspases operate in line with each other, not in parallel, to mediate the apoptosis cascade. Since recent studies have reported that activated caspase- 8 can cleave Bid, a pro-apoptotic member of the Bcl-2 family that mediates mitochondrial-dependent death pathway, then activate caspase-9 (26), the effect of PMBE on the intact Bid protein was examined to explore the relation of caspase- 8 and -9 activity. Immunoblotting (Fig. 5C) suggested that Bid underwent cleavage upon PMBE treatment in HepG2 cells. The Bid protein cleaved by caspase- 8 is likely to be involved in caspase-9 activation.

$\mathrm{NF}-\kappa \mathrm{B}$ seems to play an important role in resistance to apoptosis since it can activate the transcription of several genes involved in the suppression of cell apoptosis (16). Since the $\mathrm{Bcl}-2$ protein is one of the targets regulated by $\mathrm{NF}-\mathrm{\kappa B}$ and its expression is decreased after PMBE treatment in HepG2 cells (Fig. 5C), the activity of NF- $\mathrm{KB}$ might be inhibited by PMBE. It was reported that the degradation of NF- $\kappa \mathrm{B}$ inhibitor $\mathrm{I} \kappa \mathrm{B}-\alpha$ can been used as an indirect method to measure the presence and transcriptional activity of free and nucleus-oriented NF- $\kappa B$ (27). The results suggested the total expression of IкB- $\alpha$ was not altered in HepG2 cells, but the phosphorylation of IкB- $\alpha$ was decreased by PMBE (Fig. 5C), indicating inhibition of the activity of $\mathrm{NF}-\kappa \mathrm{B}$.

In light of these findings (Fig. 5), the induction mechanism of PMBE-induced apoptosis can be assumed. First, interaction of PMBE with the conjugate death receptor induces receptor trimerization, activating caspase- 8 . Activated caspase- 8 then catalyzes the truncation of Bid, which together with a decreases ratio of $\mathrm{Bcl}-2 / \mathrm{Bax}$, facilitates the intrinsic, mitochondrial apoptosis pathway. Activated initiator caspase- 9 can cleave executor caspase-3 to induce subsequent apoptosis events. Meanwhile, PMBE decreases the phosphorylation of NF- $\mathrm{KB}$ inhibitor IкB- $\alpha$, which decreases the ubiquitylation and degradation of IкB- $\alpha$, thereby resulting in $\mathrm{NF}-\kappa \mathrm{B}$ remaining in the cytoplasm in an inactive form, bound to IкB- $\alpha$, where it is unable to translocate to the nucleus to upregulate transcription of specific genes such as Bcl-2. Collectively, the findings demonstrate that PMBE induces apoptosis probably mediated by caspase, and is dependent on both the extrinsic and intrinsic apoptosis pathways and inhibition of NF- $\mathrm{\kappa B}$ activity.

Recent interest in the natural plant components proanthocyanidins has been stimulated by their potential protective effects on normal cells and apoptosis-inducing effects on cancer cells $(28,29)$. Until now, several kinds of proanthocyanidins, abundantly available in various parts of plants, such as seeds, fruits, bark, and berries, have been extracted from wide variety of plants such as grape, cocoa, apple, pine, sorghum, blackberry, black raspberry, blueberry, cranberry, red raspberry, and strawberry, each of which has been claimed to exert anticarcinogenic activity in cellular models of cancer. A cranberry proanthocyanidin-rich extract induces apoptosis in human esophageal adenocarcinoma cells SEG-1 cells (30). Grape seed proanthocyanidins can mediate intrinsic pathway apoptosis, including activation of caspase- $9,-3$ and a decrease in the ratio of $\mathrm{Bcl}-2 / \mathrm{Bax}$ proteins in human epidermoid carcinoma A431 cells (31), which is similar to the effect of PMBE in HepG2 cells (Fig. 5). Proanthocyanidins differ in the nature of their constitutive units, sequences, positions of interflavanic linkages, chain lengths, and presence of substituents (32). Diverse chemical structure and compounding of proanthocyanidins may explain the different effects and antitumor mechanisms. For instance, gallate groups and polymerization enhance the antiproliferative capacity of procyanidin-rich natural extracts, which suggests that natural polyphenolic extracts with a high degree of galloylation and oligomers are more suitable as potential antiproliferative agents than those containing monomers (33). Therefore, exact isolation and structure elucidation of the proanthocyanidin oligomer mixture in PMBE is needed to find the most active oligomer components or fractions for further study. A deep understanding about natural plant components will be the trend of future medical research.

In conclusion, PMBE can inhibit cell viability, cause cell cycle arrest, induce apoptosis mediated by caspases of both the extrinsic and intrinsic pathways, and inhibit NF- $\mathrm{\kappa B}$ activity in HepG2 cells in vitro. PMBE also can significantly suppress the growth of $\mathrm{H} 22$ tumors in tumor-bearing mice in vivo. These results provide a foundation for future potential development of PMBE for cancer treatment.

\section{Acknowledgements}

This work was supported by a grant from the Natural Science Foundation of Guangdong Province, China (No.2004b 10401044) and the National Talented Person Foundation of China (J0730638).

\section{References}

1. Palmer DH, Hussain SA and Johnson PJ: Gene- and immunotherapy for hepatocellular carcinoma. Expert Opin Biol Ther 5: 507-523, 2005.

2. Shu X, McCulloch M, Xiao H, Broffman M and Gao J: Chinese herbal medicine and chemotherapy in the treatment of hepatocellular carcinoma: a meta-analysis of randomized controlled trials. Integr Cancer Ther 4: 219-229, 2005.

3. Mukherjee AK, Basu S, Sarkar N and Ghosh AC: Advances in cancer therapy with plant based natural products. Curr Med Chem 8: 1467-1486, 2001.

4. Earnshaw WC: Nuclear changes in apoptosis. Curr Opin Cell Biol 7: 337-343, 1995.

5. Kundu T, Dey S, Roy M, Siddiqi M and Bhattacharya RK: Induction of apoptosis in human leukemia cells by black tea and its polyphenol theaflavin. Cancer Lett 230: 111-121, 2005.

6. Di Carlo G, Mascolo N, Izzo AA and Capasso F: Flavonoids: old and new aspects of a class of natural therapeutic drugs. Life Sci 65: 337-353, 1999.

7. Nijveldt RJ, van Nood E, van Hoorn DE, Boelens PG, van Norren $\mathrm{K}$ and van Leeuwen PA: Flavonoids: a review of probable mechanisms of action and potential applications. Am J Clin Nut 74: 418-425, 2001. 
8. Packer L, Rimbach G and Virgili F: Antioxidant activity and biologic properties of a procyanidin-rich extract from pine (Pinus maritima) bark, pycnogenol. Free Radic Biol Med 27: 704-724, 1999.

9. Cui Y, Xie H and Wang J: Potential biomedical properties of Pinus massoniana bark extract. Phytother Res 19: 34-38, 2005.

10. Fukuda J, Okamura K, Ishihara K, Mizumoto H, Nakazawa K, Ijima H, Kajiwara T and Funatsu K: Differentiation effects by the combination of spheroid formation and sodium butyrate treatment in human hepatoblastoma cell line (Hep G2): A possible cell source for hybrid artificial liver. Cell Transplantation 14: 819-827, 2005.

11. Cui YY, Xie H, Lai F and Wang JF: Preliminary study on antioxidative activations of Pius massoniana bark extract (PMBE). Food Sciences 25: 179-183, 2004.

12. Nitao JK, Birr BA, Nair MG, Herms DA and Mattson WJ: Rapid quantification of proanthocyanidins (condensed tannins) with a continuous flow analyzer. J Agric Food Chem 49: 2207-2214, 2001.

13. Desagher S, Osen-Sand A, Nichols A, Eskes R, Montessuit S, Lauper S, Maundrell K, Antonsson B and Martinou JC: Bidinduced conformational change of Bax is responsible for mitochondrial cytochrome $\mathrm{c}$ release during apoptosis. J Cell Biol 144: 891-901, 1999

14. Kluck RM, Bossy-Wetzel E, Green DR and Newmeyer DD: The release of cytochrome $\mathrm{c}$ from mitochondria: a primary site for Bcl-2 regulation of apoptosis. Science 275: 1132-1136, 1997.

15. Singh R, Pervin S and Chaudhuri G: Caspase-8-mediated BID cleavage and release of mitochondrial cytochrome c during Nomega-hydroxy-L-arginine-induced apoptosis in MDA-MB468 cells. Antagonistic effects of L-ornithine. J Biol Chem 277: 37630-37636, 2002.

16. Micheau O, Lens S, Gaide O, Alevizopoulos K and Tschopp J: NF-kappaB signals induce the expression of c-FLIP. Mol Cell Biol 21: 5299-5305, 2001.

17. Warren JM, Allen HL and Booker FL: Mineral nutrition, resin flow and phloem phytochemistry in loblolly pine. Tree Physiol 19: 655-663, 1999 .

18. Weber HA, Hodges AE, Guthrie JR, O'Brien BM, Robaugh D, Clark AP, Harris RK, Algaier JW and Smith CS: Comparison of proanthocyanidins in commercial antioxidants: grape seed and pine bark extracts. J Agric Food Chem 55: 148-156, 2007.

19. Price ML, Scoyoc SV and Butler LG: A critical evaluation of the vanillin reaction as an assay for tannin in sorghum grain. $J$ Agric Food Chem 26: 1214-1218, 1978.

20. Huynh HT and Teel RW: Selective induction of apoptosis in human mammary cancer cells (MCF-7) by pycnogenol. Anticancer Res 20: 2417-2420, 2000.

21. Huang WW, Yang JS, Lin CF, Ho WJ and Lee MR: Pycnogenol induces differentiation and apoptosis in human promyeloid leukemia HL-60 cells. Leuk Res 29: 685-692, 2005.
22. Cui YY, Xie H, Qi KB, He YM and Wang JF: Effects of Pinus massoniana bark extract on cell proliferation and apoptosis of human hepatoma BEL-7402 cells. World J Gastroenterol 11: 5277-5282, 2005.

23. Ma H, Lai F, Xie H, Wang $\mathrm{J}$ and Wang $\mathrm{H}$ : Involvement of the Bcl-2 family members in Pinus massoniana bark extract induced apoptosis in HeLa cells. Phytother Res 22: 1472-1476, 2008.

24. Huh JE, Kang KS, Ahn KS, Kim DH, Saiki I and Kim SH: Mylabris phalerata induces apoptosis by caspase activation following cytochrome c release and Bid cleavage. Life Sci 73: 2249-2262, 2003.

25. Sadowski-Debbing K, Coy JF, Mier W, Hug H and Los M: Caspases - their role in apoptosis and other physiological processes as revealed by knock-out studies. Arch Immunol Ther Exp 50: 19-34, 2002.

26. Krammer PH: CD95's deadly mission in the immune system. Nature 407: 789-795, 2000.

27. Kim KW, Kim BJ, Chung CW, Jo DG, Kim IK, Song YH, Kwon YK, Woo HN and Jung YK: Caspase cleavage product lacking amino-terminus of IkappaBalpha sensitizes resistant cells to TNF-alpha and TRAIL-induced apoptosis. J Cell Biochem 85: 334-345, 2002.

28. King M, Chatelain K, Farris D, Jensen D, Pickup J, Swapp A, O'Malley S and Kingsley K: Oral squamous cell carcinoma proliferative phenotype is modulated by proanthocyanidins: a potential prevention and treatment alternative for oral cancer. BMC Complement Altern Med 7: 22, 2007.

29. Engelbrecht AM, Mattheyse M, Ellis B, Loos B, Thomas M, Smith R, Peters S, Smith C and Myburgh K: Proanthocyanidin from grape seeds inactivates the PI3-kinase/PKB pathway and induces apoptosis in a colon cancer cell line. Cancer Lett 258: 144-153, 2007.

30. Kresty LA, Howell AB and Baird M: Cranberry proanthocyanidins induce apoptosis and inhibit acid-induced proliferation of human esophageal adenocarcinoma cells. J Agric Food Chem 56: 676-680, 2008

31. Meeran SM and Katiyar SK: Grape seed proanthocyanidins promote apoptosis in human epidermoid carcinoma A431 cells through alterations in Cdki-Cdk-cyclin cascade, and caspase-3 activation via loss of mitochondrial membrane potential. Exp Dermatol 16: 405-415, 2007.

32. Cheynier V: Polyphenols in foods are more complex than often thought. Am J Clin Nutr 81: S223-S229, 2005.

33. Lizarraga D, Lozano C, Briede JJ, van Delft JH, Tourino S, Centelles JJ, Torres JL and Cascante M: The importance of polymerization and galloylation for the antiproliferative properties of procyanidin-rich natural extracts. FEBS J 274: 4802-4811, 2007. 